\title{
Development of Worksheet Based on Scientific Approach to Improve Critical Thinking Skills
}

\author{
Submitted 28 May 2021, Revised 25 June 2021, Accepted 29 June 2021 \\ Tias Ernawati ${ }^{*}$, Sigit Sujatmika ${ }^{2}$ \\ ${ }^{1,2}$ Science Education Program, Faculty of Teacher Training and Education, \\ Universitas Sarjanawiyata Tamansiswa, Yogyakarta, Indonesia \\ Corresponding Email: *tias.ernawati@ ustjogja.ac.id
}

\begin{abstract}
This study aimed to develop and determine the advisability of chemical worksheets based on a scientific approach to improve students' critical thinking skills. The research method uses five design research steps simplified from Borg's and Gall's research and development. The subject of this research are science education program students at one university in Indonesia. Validation subject matter feasibility on the worksheets is 4.34 (best criteria), while the feasibility is 4.17 (best standards). A random assessment from several students is obtaining an average score of $98.67 \%$ (positive response). The research results conclude that a worksheet is advisable for students. Expert opinion conveys that using a scientific approach to the problems presented in the worksheet reveals stimulates, encourages, and improves critical thinking skills.
\end{abstract}

Keywords: worksheet, scientific approach, critical thinking skills

\section{INTRODUCTION}

Science plays a pivotal role in responding to issues during industrial revolution 4.0 to society 5.0. As an integral part of Science, Technology, Engineering, and Mathematics (STEM), science is expected to contribute to the review in developing basic concepts of knowledge as a solution to answer daily life problems. In terms of assessment and development of sciences, sustainable literacy is necessary. There is a critical thinking process in sustainability literacy to recognize, understand, and study scientific cases to find solutions.

Critical thinking is a mental process that seeks to clarify and evaluate the actions and activities of life (Kong, 2007). The cognitive functions of clarification and evaluation are essential in the problem-solving and decision-making processes, which encompass entire daily activities. Thus, critical thinking is one's mental attitude in the form of cognitive abilities. Critical thinking help students to think about how they reach conclusions, defend positions on complex issues, consider a variety of points of view, analyze concepts, theories, and explanations, explain problems and findings, solve problems, transfer ideas to new contexts, examine assumptions, assessing facts, and exploring implications in their thoughts and experiences (Hewitt \& Lyons, 2007).

In constructing assessments of critical thinking, educators should use open-ended tasks, real-world or "authentic" problem contexts, and structured problems that require students to go beyond recalling or restating previously learned information (Lai, 2011). In developing critical thinking skills, teachers need basic instruction that can activate students, such as teaching 
material. Wotruba and Wright in Uno (2013) revealed the seven effective learning indicators, namely: (1) good material organization, (2) effective communication, (3) mastery and enthusiasm for topics being taught, (4) positive attitudes towards students, (5) fair assessment, (6) flexibility in the learning approach, and (7) good student learning outcomes. To realize the ideal learning process, a collaboration between lecturers and students is obviously significant, supported by learning resources that include appropriate teaching materials and instructional media, methods, and strategies. Teaching materials are all forms of materials used by lecturers to help students perform in the learning processes. The teaching materials platform can be either printed or online, written or unwritten resources.

Through teaching materials, the worksheet based on a scientific approach is expected to make students more productive, creative, innovative, and effective through the strengthening of integrated attitudes, skills, and knowledge. The scientific approach is a learning model that uses scientific principles which contain a series of data collection activities through observation, questioning, experimentation, processing information or data, then communicating (Kementerian Pendidikan dan Kebudayaan, 2013). Students are directed to actively observe, ask, think, experiment, or try to convey and share what they have learned. The objectives of learning with a scientific approach include: (1) increasing intellectual abilities, especially higher-order thinking skills, (2) to form students' abilities in solving a problem systematically, (3) creating learning conditions where students feel that learning is a form of learning. There is a need (4) to obtain high learning outcomes, (5) to train students in communicating ideas, especially in writing scientific articles, and (6) to develop students' character (Machin, 2014).

Learning in a college class is also a description of circumstances that indicates the interaction process involving college students, lecturers, and learning resources in certain conditions called the learning environment. Effective learning can convey students' active participation and potential (Ernawati, 2016). The chemistry course, along with a code of IPA15106, is a compulsory course with two credit points. Chemistry learning has not implemented structured teaching materials such as a worksheet, but lecturers use textbooks and handouts. Students are dependent on the materials presented by the lecturer in the learning process. They have not fully initiated to study the chemical materials before the lecture begins. Critical thinking skills during learning are still low. Students prefer to wait for instructions from the lecturer. Most of them tend to be passive during the lesson. 
Instructional materials have some crucial roles in the learning process; one of them is to more interesting, practical, realistic, and meaningful learning (Olayinka, 2016), (Saad, 2017), (Zhang et al., 2016). Related to the problems above, the objective of this research is to develop a chemistry worksheet based on a scientific approach to improve students' critical thinking skills.

\section{METHOD}

This research is a development study using a step-by-step approach to develop Borg's and Gall's model. The research procedure was simplified into five steps, namely (1) exploratory study, (2) product design, (3) expert validation and revision, (4) limited and revised testing, and (5) mind field testing and final product (Pusat Penelitian Kebijakan dan Inovasi, 2008). This study did not reach the stage of main field testing due to various limitations experienced by the author. The steps of this research are presented in the following figure.

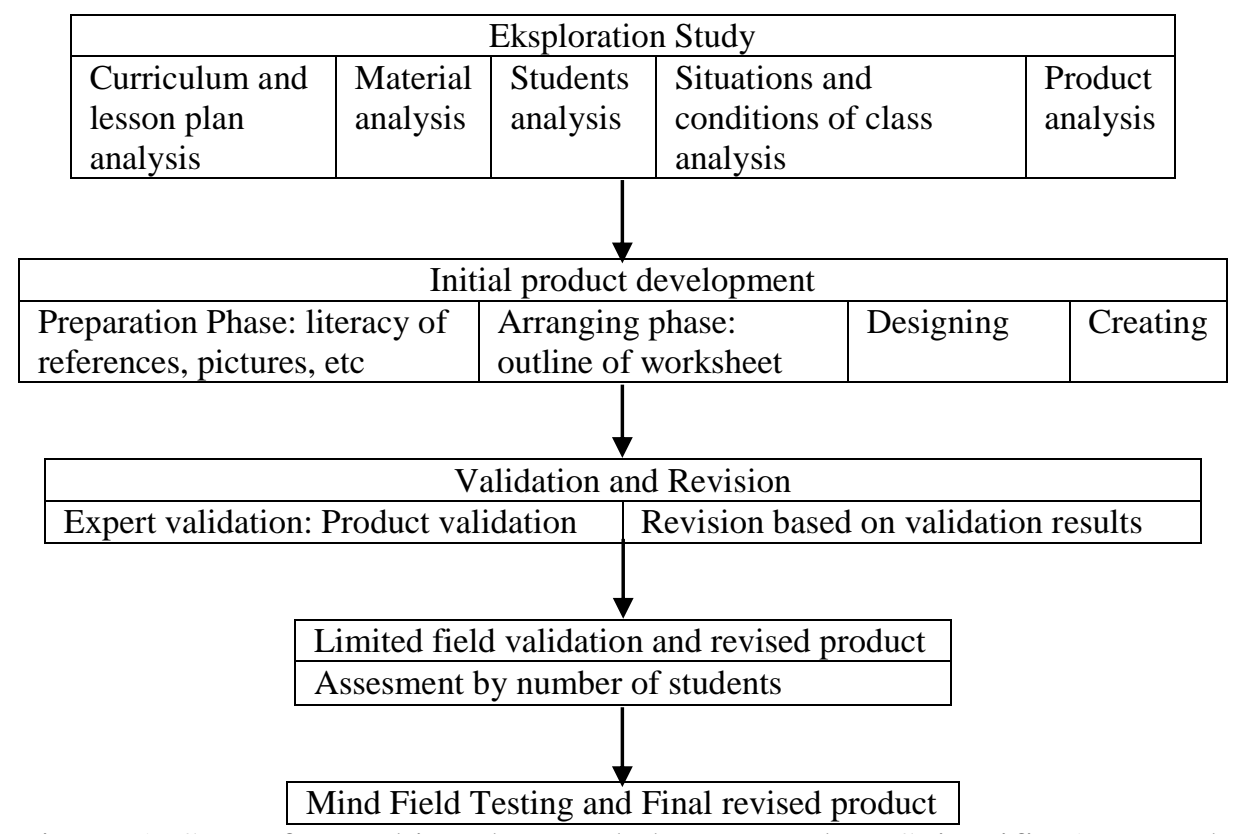

Figure 1. Steps for Making the Worksheet Based on Scientific Approach

Data collection techniques used qualitative and quantitative methods of validation for expert judgments by the Delphi technique. Validation sheets are in the form of a questionnaire of five rating Likert scales. User response is obtained from the assessment of the number of students at random.

\section{RESULTS AND DISCUSSION}

Quantitatively, the criteria and value limits of the validation resulted from the validators are to follow the criteria listed. The results of the validation in terms of the material experts and worksheet experts are presented in Table 1, Table 2, Table 3, and Table. 4 
Table 1. Validation criteria

\begin{tabular}{cc}
\hline Score & Criteria \\
\hline $\bar{X}>4$ & Best \\
$3.33<\bar{X} \leq 4$ & Good \\
$2.67<\bar{X} \leq 3.33$ & Worse \\
$2<\bar{X} \leq 2.67$ & Bad \\
$\bar{X} \leq 2$ & Worst \\
\hline
\end{tabular}

The distribution of the assessment criteria from experts is according to Table 1. To get good criteria, the expert at least gives an average score above 3.33. The results of the material expert assessment are in Table 2.

Table 2. Results of material validation by material experts

Validation Indicator Validation Item

\section{Score} E1 Advisability Content Aspect

A. The comprehensive beetwen material and lesson plan as part of learning outcomes and expected final ability

B. Material accuracy

C. Material Novelty
1. Completeness of the material

2. Comprehensive of the material

3. Profoundness of the material
4. The accuracy of concepts and definitions

5. Principle accuracy

6. Accuracy of Facts and Data

7. Accuracy of examples

8. Accuracy of exercise

9. Accuracy of pictures, diagrams, illustrations

10. Accuracy of Notations, symbols, and Icons

11. Accuracy of references

12. Comprehensive of Material to the

$\begin{array}{ll}4 & 4 \\ 4 & 4 \\ 5 & 4\end{array}$
E2

Development of Science

13. Novelty of pictures, diagrams, illustrations

14 . Novelty of references

\section{Average}

Validation Criteria : Best

\section{Advisability Presentation Aspect}
A. Presentment Technique
1. Systematic consistency of presentation in learning activities
2. Continuity of presentation
3. Continuity of Scientific Approach discussion

B. Supporting Presentment instructions
4. The ability of exercices and discussions to improve students' critical thinking skills
5.Examples of test items in each learning activity
6. Examples of exercices in each learning activity
7. The answer key to the practice exercices
8. Exercices feedback
9. Introduction
10. Glossary
11. References
12. Conclusion
C. Learning Presentation
13. Students' participation

\begin{tabular}{lll}
4 & & 5 \\
4 & & 5 \\
5 & & 4 \\
5 & & 4 \\
5 & & 4 \\
5 & & 5 \\
4 & & 4 \\
4 & & 4 \\
4 & & 5 \\
& & \\
4 & & \\
4 & & \\
4 & & \\
\multicolumn{2}{c}{4.36}
\end{tabular}




\begin{tabular}{|c|c|c|c|}
\hline \multirow[t]{2}{*}{ Validation Indicator } & \multirow[t]{2}{*}{ Validation Item } & \multicolumn{2}{|c|}{ Score } \\
\hline & & E1 & E2 \\
\hline \multirow{5}{*}{$\begin{array}{l}\text { D. Completeness of } \\
\text { presentation }\end{array}$} & 14. Part of introduction & 4 & 4 \\
\hline & 15. Part of content & 4 & 4 \\
\hline & 16. Closing section & 4 & 4 \\
\hline & Average & \multicolumn{2}{|c|}{4.28} \\
\hline & Validation Criteria : Best & & \\
\hline \multicolumn{4}{|l|}{ Language Validation } \\
\hline \multirow[t]{3}{*}{ A. Brief } & 1. Accuracy of sentence structure & 5 & 4 \\
\hline & 2. Effectiveness of sentences & 5 & 4 \\
\hline & 3. Rigidity of terms & 4 & 4 \\
\hline \multirow[t]{2}{*}{ B. Communicative } & 4. Instruction Readability & 5 & 5 \\
\hline & 5. Accuracy in Using Language Rules & 4 & 5 \\
\hline \multirow[t]{2}{*}{ C. Dialogical and Interactive } & 6. Ability to motivate instructions or information & 4 & 5 \\
\hline & 7. Ability to encourage critical thinking & 4 & 5 \\
\hline \multirow{2}{*}{$\begin{array}{l}\text { D. Comprehensive with the } \\
\text { level of development of } \\
\text { students }\end{array}$} & $\begin{array}{l}\text { 8. Comprehensive to the intellectual development } \\
\text { of students }\end{array}$ & 4 & 4 \\
\hline & $\begin{array}{l}\text { 9. Comprehensive to the level of emotional } \\
\text { development }\end{array}$ & 4 & 4 \\
\hline \multirow[t]{2}{*}{$\begin{array}{l}\text { E. Coherence and integrated to } \\
\text { way of thinking }\end{array}$} & $\begin{array}{l}\text { 10. Coherent and cohesiveness between learning } \\
\text { activities }\end{array}$ & 5 & 5 \\
\hline & $\begin{array}{l}\text { 11. Coherent and cohesiveness between } \\
\text { paragraphs }\end{array}$ & 5 & 4 \\
\hline \multirow{4}{*}{$\begin{array}{l}\text { F. Appllication of terms, } \\
\text { symbols or icons }\end{array}$} & 12. Consistency of using the term & 4 & 4 \\
\hline & 13. Consistency of using the symbols and icons & 4 & 4 \\
\hline & Average & \multirow{2}{*}{\multicolumn{2}{|c|}{4.38}} \\
\hline & Validation Criteria : Best & & \\
\hline
\end{tabular}

Table 3. displays the results of the expert validation of the worksheets. The assessment includes aspects of size, cover graphics, and appearance. While table 4 shows the results of the evaluation from users. Regarding the appearance and quality of the content.

Table 3. Results of worksheet validation from worksheet experts

\begin{tabular}{|c|c|c|c|}
\hline \multirow{2}{*}{$\begin{array}{l}\text { Validation } \\
\text { Indicator }\end{array}$} & \multirow{2}{*}{ Validation Item } & \multicolumn{2}{|c|}{ Score } \\
\hline & & $\mathbf{E 3}$ & E4 \\
\hline \multicolumn{4}{|c|}{ Graphic Appropriateness Aspect } \\
\hline A. Worksheet & 1. Comprehensive with the size of the worksheet contents & 4 & 4 \\
\hline Size & Average & \multirow{2}{*}{\multicolumn{2}{|c|}{4.00}} \\
\hline & Validation Criteria : Good & & \\
\hline B. Cover & 2. Color elements of the harmonious layout and clarify the function & 4 & 4 \\
\hline \multirow[t]{2}{*}{$\begin{array}{l}\text { Design of } \\
\text { Worksheet }\end{array}$} & $\begin{array}{l}\text { 3. Font size of titles is more dominant and proportionate to the size } \\
\text { of the book, the author's name }\end{array}$ & 4 & 4 \\
\hline & $\begin{array}{l}\text { 4. The color of the book's title contrasts with the background color } \\
\text { Average } \\
\text { Validation Criteria : Best }\end{array}$ & 4.17 & $7^{4}$ \\
\hline C. Design & 5. Placement of layout elements in consistency based on patterns & 4 & 4 \\
\hline Content of & 6. The separation between paragraphs is brief & 4 & 4 \\
\hline Worksheet & 7. Proportional print and marginal fields & 4 & 4 \\
\hline & 8. The two-page margins are side by side proportional. & 5 & 5 \\
\hline & 9. The spaces between the text and illustrations are appropriate & 5 & 4 \\
\hline & $\begin{array}{l}\text { 10. Placement of the title of learning activities, and page numbers / } \\
\text { folios do not interfere with the information }\end{array}$ & 5 & 5 \\
\hline
\end{tabular}




\begin{tabular}{lcc}
\hline Validation & Validation Item & \multicolumn{2}{c}{ Score } \\
Indicator & & E3 E4 \\
\cline { 2 - 3 } & Average & 4.33 \\
& Validation Criteria : Best & \\
\hline
\end{tabular}

Table 4. Results of the limited test assessment from students

\begin{tabular}{|c|c|c|c|c|c|c|}
\hline \multirow{2}{*}{$\begin{array}{l}\text { Validation } \\
\text { Indicator }\end{array}$} & \multirow{2}{*}{ Validation Item } & \multicolumn{5}{|c|}{ Score } \\
\hline & & M1 & M2 & M3 & M4 & M5 \\
\hline \multirow{9}{*}{$\begin{array}{l}\text { A. } \\
\text { Presentment }\end{array}$} & 1. Proportional print and marginal & 1 & 1 & 1 & 1 & 1 \\
\hline & fields & & & & & \\
\hline & 2. Proportional image size & 1 & 1 & 1 & 1 & 1 \\
\hline & 3. Images can be clearly seen & 1 & 1 & 1 & 0 & 1 \\
\hline & 4. Image contrast with the background & 1 & 1 & 1 & 1 & 1 \\
\hline & 5. The intereting image & 1 & 1 & 1 & 1 & 1 \\
\hline & $\begin{array}{l}\text { 6. Picture in comprehensive to the } \\
\text { material }\end{array}$ & 1 & 1 & 1 & 1 & 1 \\
\hline & Score Average (Percentage) & & & $96 \%$ & & \\
\hline & \multicolumn{6}{|c|}{ Response Criteria : Positive } \\
\hline B. Presentation & 7. Comprehensive of the concept & 1 & 1 & 1 & 1 & 1 \\
\hline \multirow[t]{14}{*}{ of Materials } & 8. Accuracy of definition & 1 & 1 & 1 & 1 & 1 \\
\hline & 9. Accuracy of facts and data & 1 & 1 & 1 & 1 & 1 \\
\hline & $\begin{array}{l}\text { 10. Nevelty of pictures, diagrams and } \\
\text { illustrations }\end{array}$ & 1 & 1 & 1 & 1 & 1 \\
\hline & $\begin{array}{l}\text { 11. Comprehensive of the questions } \\
\text { with the material }\end{array}$ & 1 & 1 & 1 & 1 & 1 \\
\hline & 12. Ease of understanding material & 1 & 1 & 1 & 1 & 1 \\
\hline & 13. Complete worksheet components & 1 & 1 & 1 & 1 & 1 \\
\hline & $\begin{array}{l}\text { 14. Comprehensive of scientific } \\
\text { learning steps }\end{array}$ & 1 & 1 & 1 & 1 & 1 \\
\hline & 15. Brief of sentences in paragraphs & 1 & 1 & 1 & 1 & 1 \\
\hline & $\begin{array}{l}\text { 16. Separation between paragraphs is } \\
\text { clear }\end{array}$ & 1 & 1 & 1 & 1 & 1 \\
\hline & $\begin{array}{l}\text { 17. Accuracy of Notations, symbols } \\
\text { and Icons }\end{array}$ & 1 & 1 & 1 & 1 & 1 \\
\hline & $\begin{array}{l}\text { 18. Comprehensive is a term with an } \\
\text { explanation of terms }\end{array}$ & 1 & 1 & 1 & 1 & 1 \\
\hline & $\begin{array}{l}\text { 19. Comprehensive with the material } \\
\text { sample }\end{array}$ & 1 & 1 & 1 & 1 & 1 \\
\hline & Score Average (Percentage) & & & $100 \%$ & & \\
\hline & \multicolumn{6}{|c|}{ Response Criteria : Positive } \\
\hline \multirow[t]{7}{*}{ C. Advantages } & $\begin{array}{l}\text { 20. Ease of understanding learning } \\
\text { objectives }\end{array}$ & 1 & 1 & 1 & 1 & 1 \\
\hline & $\begin{array}{l}\text { 21. Ease of understanding learning } \\
\text { instructions }\end{array}$ & 1 & 1 & 1 & 1 & 1 \\
\hline & $\begin{array}{l}\text { 22. Interest in reading worksheet } \\
\text { outside the class }\end{array}$ & 1 & 1 & 1 & 1 & 1 \\
\hline & 23. Interest in solving exercises & 1 & 1 & 1 & 1 & 1 \\
\hline & $\begin{array}{l}\text { 24. Interest in criticizing learning } \\
\text { material }\end{array}$ & 1 & 1 & 1 & 1 & 1 \\
\hline & $\begin{array}{l}\text { 25. Interest in connecting concepts in } \\
\text { daily life }\end{array}$ & 1 & 1 & 1 & 1 & 1 \\
\hline & \multicolumn{2}{|c|}{ Response Criteria : Positive } & & $100 \%$ & & \\
\hline
\end{tabular}


In this research, a worksheet-based scientific approach has been developed by five steps of design research. The worksheet contains activities that include observing, questioning, associating, experimenting, and networking. Implementing those steps of the scientific approach is expected to reach the cognitive, affective, and psychomotor domains. The worksheet also can be used to improve students' critical thinking skills. The worksheet consists of problems to teach how students deal with problems, formulate problems in the frame, and take action according to, solve, and conclude.

The first step in this research is an exploratory study. The data obtained include (1) the analysis of the curriculum and the lesson plan required as a teaching material that can facilitate students in learning the material, especially in the study of substances or matters, classification, characteristics and changes of substances, atom theories, and tables of periodical elements, ionic and molecular compounds, (2) the main points of discussion that require the identification of a representative sample of the daily life. This requires the implementation of learning based on the scientific approach, (3) students tending to begin the study when learning takes place in class. There has been no initiative to learn independently. This makes it difficult to explore the potential of students' critical thinking. (4) lecturers used teaching materials packaged in the powerpoint media by taking examples of questions in textbooks, (5) the whole subjects in the textbook can not represent materials for a semester. Lecturers need to combine learning materials from several books and other literacies so that this is considered ineffective and inefficient in learning. (6) Worksheets related to the students' needs, materials, and characteristics are set to maximize the learning processes resulting in learning outcomes and expected learning achievements.

The worksheet development begins with collecting learning materials from various sources. The draft was compiled by taking the first to fifth week-class learning achievements. This draft consists of two parts, namely worksheet 1 and worksheet 2, each of which has two learning activities. The product preparation is developed within a structure, namely title page, author's short biography, preface, a table of contents, a list of images, introduction, learning activity 1, practice questions of scientific approach discussions, summary, formative test 1 , learning activity 2, practice questions of scientific approach discussions, recaps, formative test 2 , formative tests answer keys, glossary, and bibliography.

The materials are designed in such a way that they are arranged within complete, clear, communicative, and attractive platforms. The proportion that includes the cover and design is worth considering during the development. For this reason, students will remain focused on 
the worksheet. By developing instructional material that appropriate to the needs will attract the attention of students (Sujatmika et al., 2019). The practice exercises are based on the first semester students' characteristics in the science education program of one universitay in Indonesia, where they took chemistry courses (course code: IPA15106) by introducing highlevel questions. This problem was deliberately developed by taking into account the environment as the target. This aims to make students considerate to the environment. Students do not just know but are able to mention, explain, analyze and identify examples that exist in daily life. Scientific approach discussion activities are needed to explore the students' critical thinking skills to identify existing learning materials in the environment under the instruction of the facilitator, i.e., the lecturer. Through this instruction, learning activities will become more dialogic and interactive. Instructional materials are a tool that can help teachers and students in the learning process and in making the learning more effective (Asrizal et al., 2018).

The feasibility process for worksheet drafts is through validation by material experts and worksheet experts. The qualitative data obtained from the validators and the follow-up actions are presented in Table 5 and Table 6 . There are four validators who have the qualifications of Masters in Science, Masters in Education, and Doctoral Studies. Revisions in the form of follow-up sections are based on the cases of suggestions or input as well as notes from the validators - the recommendations from the validators presented in the table below. The consultation with the validator remains continual until the worksheet is declared eligible for use in the field.

Table 5. Qualitative validation data from material experts

\begin{tabular}{|c|c|c|c|}
\hline Validation Indicator & Validation Item & Suggestion & Continuity \\
\hline $\begin{array}{l}\text { Advisability Content Aspect } \\
\text { (Material Advisable) }\end{array}$ & $\begin{array}{l}\text { Accurate of } \\
\text { References }\end{array}$ & $\begin{array}{l}\text { Applying numbers of } \\
\text { proper references }\end{array}$ & $\begin{array}{l}\text { Increasing accurate } \\
\text { references }\end{array}$ \\
\hline $\begin{array}{l}\text { Advisability Material Aspect } \\
\text { (Material Accuracy) }\end{array}$ & $\begin{array}{l}\text { Novelty of } \\
\text { References }\end{array}$ & $\begin{array}{l}\text { Increasing numbers of } \\
\text { references }\end{array}$ & $\begin{array}{l}\text { Increasing latest } \\
\text { references }\end{array}$ \\
\hline $\begin{array}{l}\text { Advisability Presentation } \\
\text { Aspect (Presentment }\end{array}$ & $\begin{array}{l}\text { The Continuity } \\
\text { of Scientific }\end{array}$ & $\begin{array}{l}\text { There is guidance from } \\
\text { the instructor or }\end{array}$ & $\begin{array}{l}\text { Creating instruction } \\
\text { procedures }\end{array}$ \\
\hline Technique) & $\begin{array}{l}\text { Approach } \\
\text { discussion } \\
\text { instructions }\end{array}$ & $\begin{array}{l}\text { lecturer related to the } \\
\text { Scientific Approach } \\
\text { instructions }\end{array}$ & \\
\hline $\begin{array}{l}\text { Advisability Supporting } \\
\text { Presentation Aspect } \\
\text { (Supporting Presentment) }\end{array}$ & Conclusion & Do not write too much & $\begin{array}{l}\text { The conclusion is } \\
\text { brief and clear }\end{array}$ \\
\hline $\begin{array}{l}\text { Advisability Presentation } \\
\text { Aspect (Comprehensive } \\
\text { Presentation) }\end{array}$ & $\begin{array}{l}\text { Part of } \\
\text { introduction }\end{array}$ & $\begin{array}{l}\text { The objectives of the } \\
\text { activity include the } \\
\text { Audience Behaviour } \\
\text { Condition Degree } \\
\text { (ABCD) }\end{array}$ & Creating ABCD \\
\hline
\end{tabular}

Table 6. Qualitative validation data from worksheet experts 


\begin{tabular}{|c|c|c|c|}
\hline Validation Indicator & Validation Item & Suggestion & Continuity \\
\hline $\begin{array}{l}\text { Advisability Graphical } \\
\text { Validation Aspect (the } \\
\text { cover design) }\end{array}$ & $\begin{array}{l}\text { The font size of the title is } \\
\text { more dominant and } \\
\text { proportionate than that of } \\
\text { the book, and the author's } \\
\text { name }\end{array}$ & $\begin{array}{l}\text { The title font size } \\
\text { should be more } \\
\text { significant than } \\
\text { that of the others }\end{array}$ & $\begin{array}{l}\text { Creating the } \\
\text { proportional design of } \\
\text { the cover }\end{array}$ \\
\hline $\begin{array}{l}\text { Advisability Graphical } \\
\text { Validation Aspect } \\
\text { (Content Design) }\end{array}$ & $\begin{array}{l}\text { Proportionate print and } \\
\text { marginal fields }\end{array}$ & $\begin{array}{l}\text { Tables created at } \\
\text { the center }\end{array}$ & $\begin{array}{l}\text { Creating tables in the } \\
\text { center }\end{array}$ \\
\hline $\begin{array}{l}\text { Advisability Graphical } \\
\text { Validation Aspect } \\
\text { (Content Design) }\end{array}$ & $\begin{array}{l}\text { The space between the text } \\
\text { and illustrations is } \\
\text { appropriate }\end{array}$ & $\begin{array}{l}\text { Keeping the } \\
\text { space consistency }\end{array}$ & $\begin{array}{l}\text { The space between the } \\
\text { text and illustrations } \\
\text { are adapted }\end{array}$ \\
\hline
\end{tabular}

Since it was advisable, the final step in this research was a limited assessment of a number of students in the science education program that choosed randomly. Students are interested in solving problems presented on the worksheet. Students will begin to use their critical thinking skills. The steps in the scientific approach can be used to rank the level of complexity in thinking. Worksheets can improve critical thinking skills (Hastuti et al., 2018). Students mentioned that the worksheet was suitable for use in the field. The students' recommendation aims to display the image and to make it bigger. According to the assessment, the responses of limited validation give positive responses.

\section{CONCLUSION}

The worksheet-based scientific approach can be developed from 5 steps which are a simplification of the Borg and Gall development model, namely exploratory study, product design, expert validation and revision, limited and revised testing, and mind field testing and final product. The validation experts state that the products have an average material advisability score of 4.34 along with its best criteria and the worksheet advisability average of 4.17 along with its best standards. The random assessment from the number of students has obtained an average score of $98.67 \%$ (positive response). Based on the results, worksheets based on a scientific approach are advisable for students studying chemistry course in the science education program.

\section{REFERENCES}

Asrizal, Amran, A., Ananda, A., Festiyed, F., \& Sumarmin, R. (2018). The development of integrated science instructional materials to improve students' digital literacy in scientific approach. Jurnal Pendidikan IPA Indonesia, 7(4), 442-450. https://doi.org/10.15294/jpii.v7i4.13613

Ernawati, T. (2016). Implementasi Scientific Approach Pada Outdoor Learning Untuk Meningkatkan Motivasi Belajar Mahasiswa Pendidikan IPA. Jurnal Pijar MIPA, 11(1), 34-38. https://doi.org/10.29303/jpm.v11i1.6 
Hastuti, P. W., Nurohman, S., \& Setianingsih, W. (2018). The Development of Science Worksheet Based on Inquiry Science Issues to Improve Critical Thinking and Scientific Attitude. Journal of Physics: Conference Series, 1097(1), 12004. https://doi.org/10.1088/1742-6596/1097/1/012004

Hewitt, P. G., \& Lyons, S. (2007). Conceptual Integrated Science. Pearson Addison Wesley.

Kementerian Pendidikan dan Kebudayaan. (2013). Peraturan Menteri Pendidikan dan Kebudayaan Nomor 65 tahun 2013 tentang Standar Proses Pendidikan Dasar dan Menengah. Kementerian Pendidikan dan Kebudayaan.

Kong, S. L. (2007). Cultivating critical and creative thinking skills. In A.G. Tan (Ed.), Creativity: A handbook for teachers (A. G. Tan (ed.)). World Scientific Publishing.

Lai, E. R. (2011). Critical Thinking: A Literature Review Research Report. http://www.pearsonassessments.com/research.

Machin, A. (2014). Implementasi pendekatan saintifik, penanaman karakter dan konservasi pada pembelajaran materi pertumbuhan. Jurnal Pendidikan IPA Indonesia, 3(1), 28-35. https://doi.org/10.15294/jpii.v3i1.2898

Olayinka, A.-R. B. (2016). Effects of Instructional Materials on Secondary Schools Students' Academic Achievement in Social Studies in Ekiti State, Nigeria. World Journal of Education, 6(1). https://doi.org/10.5430/wje.v6n1p32

Pusat Penelitian Kebijakan dan Inovasi. (2008). Metode Penelitian Pengembangan. Pusat Penelitian Kebijakan dan Inovasi.

Saad, K. M. (2017). Effects of Instructional Materi-als on Cognitive Achievement of Secondary Schools Students in Economics in Gombe State, Nigeria. Technology \& Education (JOTE), 5(2), 19-26.

Sujatmika, S., Irfan, M., Ernawati, T., Wijayanti, A., Widodo, A., Amalia, A. F., Nurdiyanto, H., \& Rahim, R. (2019). Designing E-Worksheet Based On Problem-Based Learning To Improve Critical Thinking. https://doi.org/10.4108/eai.19-10-2018.2281282

Uno, H. B. (2013). Teori Motivasi dan Pengukurannya. Bumi Aksara.

Zhang, Q., Zhang, Q., Voogt, J., \& Akker, J. van den. (2016). Inquiry-based integrative practical activities in China: A professional... Society for Information Technology \& Teacher Education International Conference, 2016(1), 2738-2745. 